\title{
MODEL PEMBELAJARAN OUTBOUND BUKU KIA TERHADAP KEMANDIRIAN KADER
}

\author{
Suprapti \\ Poltekkes Kemenkes Malang, Jl. Besar Ijen 77C Malang \\ Email: supraptisantoso@gmail.com

\section{Learning Model of KIA's Book Outbound for Increasing the Independence of Cadres}

\begin{abstract}
One of the government's efforts to decrease maternal mortality rate is by improving the mother's understanding of KIA's book by kader. Outbond learning is a simulated learning by involving the role of kader. This research used experimental research design through the use of learning model of KIA's book outbound for increasing the independence of cadres in supporting KIA's book program. The research sample was 32 with purposive sampling technique. The research was conducted in Puskesmas Ciptomulyo from July to November 2016. The result of learning model of KIA outbound book toward the independence of kader shows there are significant differences in kader responsibility $(0,033)$, initiative $(0,005)$, confident kader (0.006), and satisfaction (0.015) before and after outbound learning.
\end{abstract}

Keywords: outbound learning, independence, KIA's book

\begin{abstract}
Abstrak: Salah satu upaya pemerintah untuk menurunkan AKI adalah dengan meningkatkan pemahaman ibu tentang buku KIA oleh kader kesehatan. Pembelajaran outbond merupakan pembelajaran simulasi dengan melibatkan peran kader. Penelitian ini menggunakan desain penelitian eksperimen melalui penggunaan model pembelajaran outbound buku KIA untuk peningkatan kemandirian kader dalam mendukung program buku KIA. Sampel penelitian sebesar 32 dengan tekhnik purposive sampling. Tempat penelitian adalah Puskesmas Ciptomulyo pada bulan Juli hingga Nopember 2016. Hasil penelitian model pembelajaran outbound buku KIA terhadap kemandirian kader menunjukkan ada perbedaan yang signifikan pada tanggung jawab kader $(0,033)$, inisiatif $(0,005)$, percaya diri kader $(0,006)$, dan kepuasan $(0,015)$ sebelum dan sesudah pembelajaran outbound.
\end{abstract}

Kata Kunci: pembelajaran outbound, kemandirian, buku KIA

\section{PENDAHULUAN}

Salah satu indikator keberhasilan pelayanan kesehatan adalah pencapaian angka kematian ibu, jadi target dalam Millenium Development Goals (MDG-s) pada tahun 2015 sebesar 102 per 100.000 kelahiran hidup. Tetapi hasil Survei Demografi dan Kesehatan Indonesia (SDKI) 2012 untuk Angka Kematian Ibu (AKI) melonjak sangat signifikan menjadi 359 per 100.000 kelahiran hidup, artinya kesehatan ibu justru mengalami kemunduran dan kematian menjadi kondisi darurat yang harus mendapatkan perhatian.

Kematian ibu disebabkan oleh pendarahan, infeksi dan tekanan darah tinggi (eklampsi), terdapat sekitar $82 \%$ kematian karena melahirkan terjadi pada perempuan muda yang masih berusia kurang dari 15 tahun hingga usia 20 tahun. Berdasarkan SDKI 2012 TFR sebesar 48 kelahiran per 1.000 remaja, menimbulkan kerentanan melahirkan di usia muda. Hal ini terkait dengan kesehatan reproduksi yang relatif masih minim dan sistem reproduksi yang masih labil, sehingga akan menimbulkan resiko besar terhadap kematian saat melahirkan. Upaya pemerintah dalam mengatasi masalah tersebut, salah satunya dengan program buku KIA yang didalamnya memberikan informasi tentang kesehatan ibu selama hamil dan anak sampai usia lima tahun. Informasi ini merupakan pegangan setiap ibu hamil 
yang harus dipahami ibu dan keluarganya untuk mencegah AKI ataupun AKB. Buku KIA yang diberikan pada setiap ibu hamil memerlukan pemahaman baik untuk ibu ataupun suami/ keluarganya agar setiap saat dapat ikut secara aktif melakukan pemantauan kesehatan untuk ibu ataupun anak. Untuk memberikan pemahaman perlu dilakukan berulang-ulang oleh tenaga terampil baik oleh nakes ataupun oleh yang lainnya, salah satunya adalah kader kesehatan sebagai ujung tombak pelaksana program buku KIA.

Kader kesehatan masyarakat adalah lakilaki atau wanita yang dipilih oleh masyarakat dan dilatih untuk menangani masalah-masalah kesehatan perseorangan maupun masyarakat serta untuk bekerja dalam hubungan yang amat dekat dengan tempat-tempat pemberian pelayanan kesehatan (Efendi dan Makhfudli, 2009). Adapun tugas-tugas kader dalam pelayanan kesehatan terbatas pada bidangbidang yang pernah diajarkan kepada mereka. Dengan demikian, kader tidak diharapkan menyelesaikan semua masalah yang dihadapinya, tetapi mereka diharapkan mampu dalam menyelesaikan masalah umum yang terjadi di masyarakat dan mendesak untuk diselesaikan. Oleh karenanya kader diharapkan memiliki kemandirian dalam menjalankan program buku KIA, dengan kemandirian yang dimiliki kader memberikan kepercayaan akan kemampuan diri untuk menyelesaikan persoalan tanpa bantuan khusus dari orang lain.

Pembelajaran yang diberikan kepada kader tidak akan sama dengan pembelajaran formal yang secara tertutup dengan acuan program, akan tetapi materi yang diberikan pada kader adalah kegiatan sederhana yang dapat mendorong penggerakan masyarakat untuk: 1) Perilaku Hidup Bersih dan Sehat (PHBS), 2) Pengamanan terhadap masalah kesehatan di desa, 3) Upaya penyehatan lingkungan, 4)
Peningkatan kesehatan ibu,bayi dan anak balita,5) Pemasyarakatan Keluarga Sadar Gizi (Kadarzi) sesuai dengan program yang dicanangkan oleh kementrian kesehatan (Meilani, 2009).

Salah satu cara pembelajaran yang dapat dilakukan dengan memberikan pengalaman simulasi yang melibatkan peran kader dalam kegiatan langsung dengan masyarakat. Pengalaman itu dapat berupa outbound. Susanta (2010) menjelaskan bahwa outbound dapat diartikan out of boundary, dapat diterjemahkan secara bebas sebagai keluar dari lingkungan hidup, batas, atau kebiasaan. Outbound merupakan sarana penambah wawasan dan pengetahuan yang didapat dari serangkaian pengalaman berpetualangan, sehingga dapat memacu kreativitas dan melatih kemandirian seseorang. Dasar pelatihan outbound menganut prinsip learning by doing trial and refinement (belajar sambil mengulang-ulang dan berusaha untuk memperbaiki) serta lifelong learning (belajar sepanjang hayat).

Tujuan dilakukan penelitian ini adalah untuk mengetahui pengaruh media pembelajaran buku outbound KIA terhadap peningkatan kemandirian kader.

\section{METODE PENELITIAN}

Penelitian ini menggunakan desain penelitian eksperimen melaluipenggunaan model pembelajaran outbound buku KIA untuk peningkatan kemandirian kader dalam mendukung program buku kesehatan ibu dan anak (KIA). Populasi dalam penelitian ini adalah kader kesehatan yang berada Puskesmas Ciptomulyo sebesar 169 responden. Sampel dalam penelitian sebesar 32 dengan tekhnik purposive sampling dengan perhitungan kader yang memenuhi kriteria inklusi: 1) kader aktif, 2) minimal menjadi kader 2 tahun. Tempat penelitian adalah Puskesmas Ciptomulyo pada bulan Juli-Nopember 2016. 
Variabel penelitian menggunakan dua variabel, yaitu variabel depeden pembelajaran outbound buku KIA, sedangkan variabel independen kemandirian kader (tanggungjawab, inisiatif, percaya diri, dan kepuasan). Teknik pengumpulan data yang digunakan dalam penelitian ini adalah dengan 1) pengisian kuesioner untuk pengetahuan tentang buku KIA, 2) permainan dengan board game buku KIA untuk kemandirian mencakup tanggung jawab, inisiatif, percaya diri, dan kepuasan. responden (kader). Teknik analisis data dilakukan dalam penelitian ini terdiri dari 3 tahapan sebagai berikut: 1) tersusunnya permainan / board game dan tersusunnya instumen penilaian, 2) tercatatnya hasil perkembangan kemandirian kader dalam setiap permainan, 3) menyusun peningkatan kemandirian kader dalam melaksanakan setiap game guna mendukung penerapan buku KIA

\section{HASIL PENELITIAN}

Karakteristik responden berdasarkan usia diketahui bahwa usia yang terbesar adalah usia tidak reproduktif sebesar $71.88 \%$ dan $28.13 \%$ usia produktif.
Berdasarkan pendidikan yang dapat dikatagorikan tinggi adalah pendidikan mulai SMA sampai PT sedangkan rendah adalah SMP kebawah, hasil penelitian menunjukkan sebagian besar responden memiliki pendidikan tinggi sebesar $71.88 \%$ dan $28.13 \%$ berpendidikan rendah.

Berdasarkan lama menjadi kader, sebagian besar responden menjadi kader kurang dari 8 tahun sebesar $53.13 \%$ dan 46.88 lebih dari 8 tahun.

Berdasarkan pengetahuan reponden terhadap buku KIA, sebagian besar memiliki pengetahuan yang kurang yaitu 19 orang $(59.38 \%)$ dan $40.63 \%$ memiliki pengetahuan yang baik.

Selanjutnya dengan pengujian hipotesis penelitian dengan menggunakan $t$-test dalam penerapan metode out bound dalam kemandirian kader terhadap program buku KIA didapatkan hasil.

Dengan uji $t$-test diketahui bahwa responden memiliki rerata tanggung jawab, inisiatif, percaya diri dan kepuasan lebih tinggi sesudah perlakuan kedua dibandingkan setelah perlakukan pertama yang bias dilihat dari hasil statistik dengan $t$-test

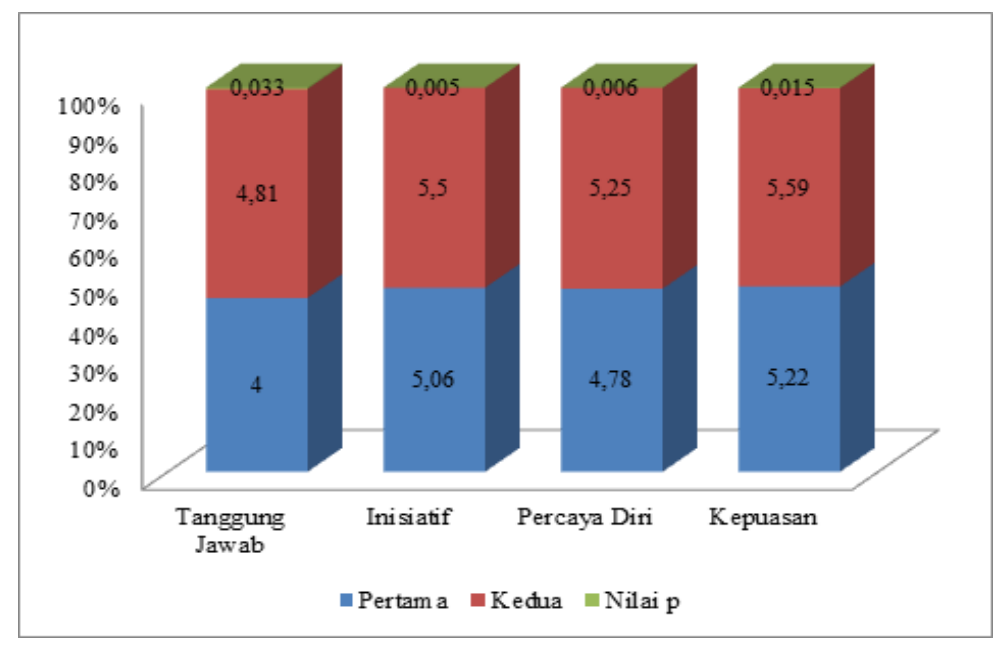

Gambar 1. Penerapan Metode Outbound dalam Kemandirian Kader 
menunjukkan ada perbedaan yang signifikan pada tanggung jawab kader $(0,033)$, inisiatif $(0,005)$, percaya diri kader $(0,006)$, dan kepuasan $(0,015)$

\section{PEMBAHASAN}

Berdasarkan hasil penelitian dari 32 responden terkait dengan board game buku KIA untuk mengetahuikemandirian kader dalam program buku KIA yang dilihat dari tanggung jawab, inisiatif, percaya diri, dan kepuasan menjadi kader. Hal ini terkait bahwa kader adalah seorang tenaga sukarela yang direkrut dari, oleh dan untuk masyarakat, yang bertugas membantu kelancaran pelayanan kesehatan (Effendy dkk., 2009). Disamping itu kader merupakan tenaga masyarakat yang dianggap paling dekat dengan masyarakat. Dengan kriteria pemilihan kader kesehatan adalah sanggup bekerja secara sukarela, mendapat kepercayaan dari masyarakat serta mempunyai kredibilitas yang baik dimana perilakunya menjadi panutan masyarakat, memiliki jiwa pengabdian yang tinggi, mempunyai penghasilan tetap, pandai baca tulis, sanggup membina masyarakat sekitarnya.

Kesehatan bukan saja tanggung jawab tenaga kesehatan, namun semua orang bertanggung jawab terhadap kesehatan. Oleh karena itu sangat diperlukan bagi semua orang untuk dapat mengenali tanda bahaya dari ancaman kesehatan terutama pada ibu dan anak. Bila sejak awal tanda bahaya ini dapat terdeteksi maka, penatalaksanaan awal juga akan semakin cepat dilaksanakan oleh tenaga terampil. Oleh sebab itu, seorang kader perlu dilatih terkait dengan program buku kesehatan ibu dan anak (KIA) (Depkes RI, 2008).

Pelatihan akan membuat seseorang memiliki sikap terus belajar, hal ini penting untuk memberikan kemandirian kader, menurut Fatimah (2006) yang menjelaskan bahwa kemandirian merupakan suatu untuk bersikap mandiri dalam menghadapi situasi di lingkungan, sehingga individu pada akhirnya mampu berpikir dan bertindak sendiri tanpa bantuan orang lain dan mampu bertanggung jawab atas segala kegiatan yang dilakukannya, melakukan sesuatu atas kemampuan sendiri, kemampuan melakukan aktivitas, membuat keputusan, mengerjakan tugas rutinnya, keinginan untuk menjadi pribadi yang lebih baik dengan tujuan untuk menjadi pribadi yang produktif.

Hasil penelitian menunjukkan dari 32 responden, di mana $71,88 \%$ responden merupakan kelompok pendidikan tinggi (SMA dan PT) dan 53,13\% telah menjadi kader $<8$ tahun. Namun tingkat pendidikan dan lamanya menjadi kader belum bisa memberikan jaminan bahwa akan memberikan pengetahuan terkait dengan program buku KIA, hal ini sesuai dengan hasil penelitian dimana responden memiliki pengetahuan yang kurang yaitu sebesar 59,38\% .

Melalui penelitian ini dilakukan dua (2) kali pembelajaran metode out bound pada kader terhadap kemandiaran kader dalam program buku KIA didapatkan hasil statistik menggunakan t-test menunjukkan ada perbedaan yang signifikan pada tanggung jawab kader $(0,033)$, inisiatif $(0,005)$, percaya diri kader $(0,006)$, dan kepuasan $(0,015)$ berdasarkan sebelum dan sesudah perlakuan. Secara teori outbound berarti proses mencari pengalaman melakukan kegiatan di alam terbuka (Ancok, 2002). Demikian pula Susanta (2010) menjelaskan bahwa outbound dapat diartikan out of boundary, dapat diterjemahkan secara bebas sebagai keluar dari lingkungan hidup, batas, atau kebiasaan. Dengan demikian pembelajaran outbound merupakan sarana penambah wawasan dan pengetahuan yang didapat dari serangkaian pengalaman berpetualangan, sehingga dapat memacu kreativitas dan melatih kemandirian seseorang. Pengalaman kader dalam penelitian ini dieksplorasikan melalui hasil pilihan kartu yang dipilih untuk mengukur kemandirian kader dalam 
tanggung jawab, inisiatif, percaya diri dan kepuasan. Dari hasil penelitian ini dapat disimpulkan bahwa tingkat pendidikan dan lamanya menjadi kader belum bisa memberikan jaminan bahwa akan memberikan pengetahuan terkait dengan program buku KIA.

\section{PENUTUP}

Hasil penelitian model pembelajaran outbound buku KIA terhadap kemandirian kader menunjukkan ada perbedaan yang signifikan pada tanggung jawab kader $(0,033)$, inisiatif $(0,005)$, percaya diri kader $(0,006)$, dan kepuasan $(0,015)$ sebelum dan sesudah pembelajaran outbound.

Pembelajaran metode out bound pada kader terhadap kemandirian kader terkait tanggung jawab, inisiatif, percaya diri serta kepuasan kader dalam program buku KIA dengan metode pembelajaran board game menimbulkan interaksi secara langsung dengan responden lain sehingga akan menciptakan situasi yang kondusif dalam sharing pengalaman, sehingga akan lebih membantu adanya kemandirian kader, baik tanggung jawab, inisiatif, percaya diri serta kepuasan dalam melaksanakan program buku KIA.

\section{DAFTAR PUSTAKA}

Ancok, Djamaluddin. (2002). OB Management Training. Yogyakarta: UII-Press.

Depkes RI. 2008. Buku Kesehatan Ibu dan Anak Provinsi Jawa Timur. Jakarta : Departemen Kesehatan dan JICA (Japan International Cooperation Agency)

Effendi, F. dan Makhfudli. (2009). Keperawatan Kesehatan Komunitas Teori dan Praktik dalam Keperawatan. Jakarta : Salemba Medika

Fatimah, E. 2006. Psikologi Perkembangan. Bandung: CV Pustaka Setia

Meilani, N. (2009). Kebidanan Komunitas. Yogyakarta: Fitramaya

Susanta, A. (2010). Outbound Profesional. Yogyakarya: Andi Offset. 